\title{
Analisis Miskonsepsi Siswa SMP pada Materi Operasi Hitung Bentuk Aljabar
}

\author{
Herikeu Meidia Sari ${ }^{1}$ dan Ekasatya Aldila Afriansyah ${ }^{2 *}$ \\ 1,2* Program Studi Pendidikan Matematika, IPI Garut \\ Jalan Terusan Pahlawan No 32 Sukagalih, Garut, Jawa Barat, Indonesia \\ herikeumeidi@gmail.com; ekasatyafriansyah@institutpendidikan.ac.id
}

Artikel diterima: 18-04-2020, direvisi: 20-09-2020, diterbitkan: 30-09-2020

\begin{abstract}
Abstrak
Rendahnya kemampuan pemahaman konsep siswa pada materi operasi hitung bentuk aljabar menjadi salah satu permasalahan yang ditemui saat belajar materi Aljabar. Banyak miskonsepsi yang ditemukan pada materi operasi hitung bentuk aljabar. Tujuan dari penelitian ini adalah untuk mengetahui bentuk miskonsepsi yang dialami siswa pada materi operasi hitung bentuk aljabar. Metode penelitian yang digunakan adalah metode kualitatif. Penelitian dilaksanakan di SMP Negeri 1 Cibatu kelas VII-H yang berjumlah sebanyak 32 siswa dengan 3 siswa dipilih secara purposive sampling untuk dijadikan partisipan pilihan. Teknik analisis data secara deskriptif melihat hasil jawaban siswa, hasil wawancara, serta dokumentasi menggunakan model Miles and Huberman, sehingga triangulasi data terpenuhi. Dari hasil penelitian ditemukan beberapa miskonsepsi yang dialami siswa pada materi operasi hitung bentuk aljabar yang dikategorikan dalam empat jenis, diantaranya miskonsepsi generalisasi, miskonsepi notasi, miskonsepsi pengartian huruf dan misonsepsi aplikasi aturan. Diketahuinya keempat miskonsepsi ini diharapkan guru-guru dapat lebih waspada saat mengajar materi aljabar terhadap keempat miskonsepsi ini.

Kata Kunci: kemampuan pemahaman konsep, miskonsepsi, operasi hitung bentuk aljabar, metode kualitatif.
\end{abstract}

\section{Analysis of Middle School Students' Misconceptions on the Material of Calculating Operations in Algebraic Forms}

\begin{abstract}
The low ability of students to understand concepts in the algebraic arithmetic operation material is one of the problems encountered when learning algebra material. Many misconceptions are found in the arithmetic operation material in algebraic form. The purpose of this study was to determine the form of misconceptions experienced by students in the algebraic form of arithmetic operations. The research method used is qualitative. The research was conducted at SMP Negeri 1 Cibatu class VII-H, amounting to 32 students with 3 students selected by purposive sampling to be selected participants. The descriptive data analysis technique saw the results of students' answers, interviews, and documentation using the Miles and Huberman model so that data triangulation was fulfilled. From the results of the study, it was found that several misconceptions experienced by students in the algebraic arithmetic operation material were categorized into four types, including generalization misconceptions, notation misconceptions, letter interpreting misconceptions, and rule application misconceptions. Knowing these four misconceptions, it is hoped that teachers will be more vigilant when teaching algebraic material regarding these four misconceptions.

Keywords: ability to understand concepts, misconceptions, arithmetic operations in algebraic forms, qualitative methods
\end{abstract}




\section{Pendahuluan}

Salah satu tujuan dari mata pelajaran matematika menurut Badan Standar Nasional Pendidikan (Pendidikan, 2006) yaitu memahami, menjelaskan, dan mengaplikasikan konsep. Hal ini dikarenakan matematika merupakan salah satu mata pelajaran yang banyak menekankan pada konsep (Afriansyah, 2015). Sedangkan, konsep itu sendiri merupakan suatu hal yang paling mendasar untuk memahami suatu materi. Jika terdapat konsep yang tidak dipahami, maka secara otomatis berpengaruh pada pemahaman konsep lainnya, dikarenakan keterkaitan antar konsep (Afriansyah, 2012). Oleh sebab itu, tujuan mata pelajaran matematika akan tercapai apabila para siswa belajar matematika dengan pemahaman, dan secara aktif membangun pengetahuan baru dari pengalaman serta pengetahuan sebelumnya.

Salah satu materi matematika yang memuat banyak konsep di dalamnya yaitu aljabar, karena itu bentuk aljabar menempati posisi khusus dalam kurikulum matematika menengah. Konsep-konsep aljabar erat kaitannya dengan masalah di kehidupan sehari-hari yang dijumpai oleh siswa (Utami, 2017), maka penanaman konsep awal untuk materi bentuk aljabar pada siswa SMP sangat penting karena masih mendasar. Selain itu, kemampuan berpikir siswa SMP berkembang sedemikian rupa sehingga dapat dengan mudah membayangkan banyak alternatif pemecahan masalah beserta kemungkinan akibat atau hasilnya.

Pada kenyataannya, pemecahan permasalahan kompleks dan abstrak masih menjadi hambatan yang dialami oleh siswa SMP (Afriansyah, 2014) dikarenakan aljabar merupakan salah satu cabang matematika yang rentan dengan miskonsepsi. Hal ini disampaikan pula oleh Afriansyah (2016) dan Nurmawanti \& Sulandra (2020), simbol memiliki interpretasi berbeda sehingga siswa berpeluang mengalami miskonsepsi.

Miskonsepsi menurut Iryani, Tandililing, \& Hamdani (2018) adalah konsepsikonsepsi lain yang tidak sesuai dengan konsepsi keilmuan secara umum. Leinhardt, Zaslavsky, \& Stein (Herutomo dan Saputro, 2014) mendefinisikan miskonsepsi sebagai pemahaman yang salah dalam pengetahuan siswa yang terjadi secara berulang dan eksplisit. Selain itu, Jumadi \& Hamdani (2018) menyebutkan bahwa miskonsepsi adalah konsepsi-konsepsi yang lain yang tidak sesuai dengan konsepsi ilmuwan secara umum. Adapun Brown (Utami, 2017) mendefinisikan miskonsepsi sebagai penjelasan yang salah dan suatu gagasan yang tidak sesuai dengan pengertian ilmiah yang diterima para ahli. Sedangkan menurut Novak (Utami, 2017), miskonsepsi merupakan suatu interpretasi konsep-konsep dalam suatu pernyataan yang tidak dapat diterima. Berdasarkan pendapat para ahli tersebut dapat disimpulkan bahwa miskonsepsi adalah 
suatu bagian kerangka konsep yang salah tetapi dianggap benar oleh siswa sehingga terjadi kesalahan yang muncul secara berulang atau konsisten.

Dalam hasil penelitian yang telah dilakukan oleh peneliti terdahulu, terdapat miskonsepsi siswa SMP yang ditemukan pada materi aljabar khususnya dalam operasi hitung bentuk aljabar, salah satunya yaitu dapat dilihat dari hasil penelitian Utami (2017), dimana siswa mengalami miskonsepsi dalam menjumlahkan dan mengurangkan koefisien dengan konstanta. Siswa menjumlahkan $5 x+7=12 x, 2 x-5=3 x$. Siswa juga mengalami miskonsepsi dengan menganggap operasi penjumlahan sebagai operasi perkalian, dimana siswa mengerjakan $x+5=5 x$.

Dari uraian sebelumnya, permasalahan miskonsepsi telah bermunculan sejak lampau, karena dengan adanya miskonsepsi, proses belajar siswa menjadi terhambat dan memungkinkan siswa untuk membuat kesalahan (Afriansyah, 2013) selama belajar materi aljabar dan menyelesaikan materi terkait lainnya. Oleh karena itu, peneliti mengadakan penelitian mengenai analisis miskonsepsi siswa SMP pada materi operasi hitung bentuk aljabar, agar diperoleh pandangan global mengenai miskonsepsi dan kemampuan siswa pada materi operasi hitung bentuk aljabar.

\section{Metode}

Metode penelitian yang digunakan dalam penelitian ini adalah metode kualitatif (Afriansyah, Puspitasari, Luritawaty, Mardiani, \& Sundayana, 2019). Subyek dalam penelitian ini yaitu siswa SMP Negeri 1 Cibatu kelas VII-H tahun ajaran 2019/2020 yang berjumlah sebanyak 32 siswa dengan 3 siswa dipilih secara purposive sampling atau pengambilan sampel sumber data dengan pertimbangan tertentu, yaitu dengan berdasarkan siswa berkemampuan tinggi, siswa berkemampuan sedang dan siswa berkemampuan rendah untuk dijadikan partisipan wawancara. Adapun pengambilan siswa partisipan yaitu berdasarkan hasil diskusi bersama guru matematika yang bersangkutan. Teknik pengumpulan data yang dilaksanakan dalam penelitian ini yaitu melalui observasi, tes tertulis dan wawancara.

Sedangkan teknik analisis data dalam penelitian ini yaitu menggunakan teknik analisis model Miles and Huberman (Sugiyono, 2018), dimana pada tahap reduksi data, peneliti menganalisis hasil pekerjaan siswa untuk mengetahui bentuk miskonsepsi yang dialami siswa pada materi operasi hitung bentuk aljabar dan kemudian mengklasifikasikan bentuk miskonsepsi tersebut dalam empat bentuk miskonsepsi. Selanjutnya yaitu mentranskip hasil wawancara partisipan. Pada tahap penyajian data, peneliti menyajikan data hasil tes dan transkip wawancara yang telah direduksi dalam 
bentuk tabel, diagram dan deskripsi. Pada tahap penarikan kesimpulan, peneliti mulai menyimpulkan data yang telah disajikan serta disesuaikan dengan rumusan masalah yang telah ditetapkan, yaitu mengetahui bentuk miskonsepsi yang dialami siswa SMP pada materi operasi hitung bentuk aljabar.

\section{Hasil dan Pembahasan}

Berdasarkan hasil analisis miskonsepsi, diperoleh banyak siswa yang mengalami miskonsepsi pada materi operasi hitung bentuk aljabar, seperti yang ditunjukkan pada Tabel 1. hasil pekerjaan siswa saat pretest pada soal operasi hitung bentuk aljabar mengalami beberapa miskonsepsi, diantaranya miskonsepsi generalisasi sebanyak 130 (45,14\%), miskonsepsi notasi sebanyak 27 (9,38\%), miskonsepsi pengartian huruf sebanyak 46 (15,97\%), miskonsepsi aplikasi aturan sebanyak 23 (7,98\%). Sedangkan siswa yang tidak menjawab sebanyak 14 (4,86\%) dan siswa yang menjawab sebanyak 48 (16,67\%).

Tabel 1.

Data Hasil Analisis Pekerjaan Siswa Pretest pada Soal Operasi Hitung Bentuk Aljabar

\begin{tabular}{lccc|}
\hline $\begin{array}{c}\text { Bentuk Hasil } \\
\text { Pekerjaan } \\
\text { Siswa }\end{array}$ & $\begin{array}{c}\text { Soal } \\
\text { Bentuk } \\
\text { Uraian }\end{array}$ & $\begin{array}{c}\text { Soal } \\
\text { Bentuk } \\
\text { Option }\end{array}$ & Jumlah \\
\hline $\begin{array}{l}\text { Miskonsepsi } \\
\text { Generalisasi }\end{array}$ & $\begin{array}{c}60 \\
(37,50 \%)\end{array}$ & $\begin{array}{c}70 \\
(54,69 \%)\end{array}$ & $\begin{array}{c}130 \\
(45,14 \%)\end{array}$ \\
\hline $\begin{array}{l}\text { Miskonsepsi } \\
\text { Notasi }\end{array}$ & 19 & 8 & 27 \\
$(11,88 \%)$ & $(6,25 \%)$ & $(9,38 \%)$ \\
\hline $\begin{array}{l}\text { Miskonsepsi } \\
\text { Pengartian }\end{array}$ & 28 & 18 & 46 \\
Huruf & $(17,50 \%)$ & $(14,06 \%)$ & $(15,97 \%)$ \\
\hline $\begin{array}{l}\text { Miskonsepsi } \\
\text { Pengaplikasian }\end{array}$ & $(13,75 \%)$ & 1 & 23 \\
Aturan & & $0,78 \%)$ & $(7,98 \%)$ \\
\hline
\end{tabular}

\begin{tabular}{|lccc|} 
Tidak Jawab & 9 & 5 & 14 \\
& $(5,62 \%)$ & $(3,91 \%)$ & $(4,86 \%)$ \\
\hline Benar & 22 & 26 & 48 \\
& $(13,75 \%)$ & $(20,31 \%)$ & $(16,67 \%)$ \\
\hline
\end{tabular}

Miskonsepsi didapat berdasarkan hasil pekerjaan dari siswa yang tergolong berkemampun tinggi, sedang, dan rendah (lihat Gambar 1) menunjukkan hasil pekerjaan siswa berkemampuan rendah $\left(\mathrm{S}_{14}\right)$ pada nomor satu saat pretest, mengalami kesalahan dalam menentukan unsur-unsur dalam bentuk aljabar, yaitu menganggap koefisien sebagai suku yang paling depan, sementara variabel berada pada suku setelahnya, kesalahan ini termasuk bentuk miskonsepsi generalisasi.

\section{Kopfisien $=a$, Varibbel $: 12 b \quad$ Konstanta $=13$}

Gambar 1. Hasil Pekerjaan $\mathrm{S}_{14}$ Pretest Nomor 1.

Terdapat juga hasil pekerjaan siswa yang mengalami kesalahan dalam mengoperasikan bentuk aljabar $9 y^{2}-4 x y+5 y+7 y^{2}+3 x y, \quad$ (lihat Gambar 2) yang menunjukkan hasil pekerjaan siswa berkemampuan tinggi $\left(\mathrm{S}_{9}\right)$ pada nomor dua saat pretest. Dimana siswa $S_{9}$ mengalami miskonsepsi notasi pada pengoperasian $(-4 x y+3 x y)$ karena menganggap notasi negatif $(-)$ di depan suku bukan merupakan satu kesatuan, sehingga hasilnya $7 x y$ dan memunculkan kembali notasi negatif $(-)$ tersebut pada hasil akhirnya menjadi $-7 x y$, kesalahan ini termasuk miskonsepsi notasi. 


$$
\begin{aligned}
& \text { 2. } 9 y^{2}-4 x y+5 y+7 y^{2}+3 x y \\
& \left(9 y^{2}+7 y^{2}\right)+(-4 x y+3 x y)+5 y \\
& 16 y^{2}-7 x y+5 y
\end{aligned}
$$

Gambar 2. Hasil Pekerjaan $\mathrm{S}_{9}$ Pretest Nomor 2.

Selain itu, terdapat juga siswa yang mengalami kesalahan dalam menentukan bentuk aljabar berdasarkan jumlah suku (lihat Gambar 3), yaitu hasil pekerjaan siswa berkemampuan sedang $\left(\mathrm{S}_{3}\right)$ pada nomor tiga saat pretest, menunjukkan kesalahan dalam menentukan suku binomial. Dimana $\mathrm{S}_{3}$ memilih ii. $2 x^{2}+x$ dan iii. $x^{2}+2 x-3$ serta tidak menyertakan alasannya. Sejalan dengan penelitian Ramdani, Hartoyo, \& Mirza (2015) yaitu siswa menganggap suku binomial ditentukan dari jumlah variabel $x$, sehingga dapat dikatakan siswa mengalami miskonsepsi notasi.

$$
\begin{aligned}
& \text { 3. ii. } 2 x^{2}+x \\
& \text { iii. } x^{2}+2 x-3
\end{aligned}
$$

Gambar 3. Hasil Pekerjaan $\mathrm{S}_{3}$ Pretest Nomor 3.

Selain itu, terdapat juga siswa yang mengalami kesalahan dalam mengaplikasikan aturan (lihat Gambar 4) saat pretest yaitu hasil pekerjaan siswa berkemampuan rendah $\left(\mathrm{S}_{14}\right)$ pada nomor empat, dimana $\mathrm{S}_{14}$ mengalami kesalahan dalam mengoperasikan pangkat pada konsep operasi perkalian bentuk aljabar yaitu $\left(3 y^{3} \times 4 y^{4}\right), \quad S_{14}$ mengaplikasian operasi perkalian pada pangkatnya, hasilnya $12 y^{12}$. Selain itu, $\mathrm{S}_{14}$ melakukan kesalahan penulisan ulang soal $6 y$ seharusnya $6 y^{5}$, kesalahan itu termasuk miskonsepsi pengaplikasian aturan.

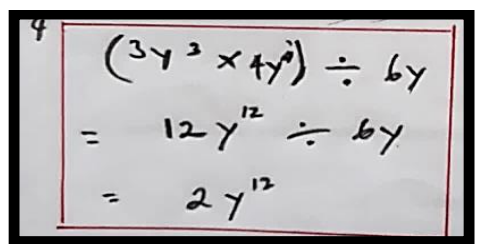

Gambar 4. Hasil Pekerjaan $\mathrm{S}_{14}$ Pretest Nomor 4.

Selanjutnya peneliti mengadakan tes akhir atau posttest. Pada hasil analisis posttest ditemukan juga miskonsepsi yang dialami siswa pada soal operasi hitung bentuk aljabar. Kemudian untuk mengkonfirmasi dan menggali lebih dalam mengenai miskonsepsi yang dialami siswa, maka peneliti mengadakan wawancara pada siswa partisipan yaitu $S_{9}$ sebagai siswa berkemampuan tinggi, $S_{3}$ sebagai siswa berkemampuan sedang, dan $\mathrm{S}_{14}$ sebagai siswa berkemampuan rendah. Data hasil analisis pekerjaan siswa posttest pada soal operasi hitung bentuk aljabar disajikan pada Tabel 2, dimana siswa dengan miskonsepsi generalisasi sebanyak 112 (38,89\%), siswa dengan miskonsepsi notasi sebanyak 18 (6,25\%), miskonsepsi pengartian huruf sebanyak 12 (4,17\%), miskonsepsi pengaplikasian aturan sebanyak 19 (6,60\%). Sedangkan untuk siswa yang tidak menjawab sebanyak 6 $(2,08 \%)$, dan siswa yang menjawab dengan benar sebanyak 121 (42,01\%).

Tabel 2.

Data Hasil Analisis Pekerjaan Siswa Posttest pada Soal Operasi Hitung Bentuk Aljabar

\begin{tabular}{cccc}
\hline $\begin{array}{c}\text { Bentuk Hasil } \\
\text { Pekerjaan } \\
\text { Siswa }\end{array}$ & $\begin{array}{c}\text { Soal } \\
\text { Bentuk } \\
\text { Uraian }\end{array}$ & $\begin{array}{c}\text { Soal } \\
\text { Bentuk } \\
\text { Option }\end{array}$ & Jumlah \\
\hline Miskonsepsi & 58 & 54 & 112 \\
Generalisasi & $(36,25 \%)$ & $(42,19 \%)$ & $(38,89 \%)$
\end{tabular}




\begin{tabular}{|c|c|c|c|}
\hline $\begin{array}{l}\text { Miskonsepsi } \\
\text { Notasi }\end{array}$ & $\begin{array}{c}14 \\
(8,75 \%)\end{array}$ & $\begin{array}{c}4 \\
(3,12 \%)\end{array}$ & $\begin{array}{c}18 \\
(6,25 \%)\end{array}$ \\
\hline $\begin{array}{l}\text { Miskonsepsi } \\
\text { Pengartian } \\
\text { Huruf }\end{array}$ & $\begin{array}{c}3 \\
(1,88 \%)\end{array}$ & $\begin{array}{c}9 \\
(7,03 \%)\end{array}$ & $\begin{array}{c}12 \\
(4,17 \%)\end{array}$ \\
\hline $\begin{array}{l}\text { Miskonsepsi } \\
\text { Pengaplikasian } \\
\text { Aturan }\end{array}$ & $\begin{array}{c}19 \\
(11,88 \%)\end{array}$ & $\begin{array}{c}0 \\
(0,00 \%)\end{array}$ & $\begin{array}{c}19 \\
(6,60 \%)\end{array}$ \\
\hline Tidak Jawab & $\begin{array}{c}5 \\
(3,12 \%) \\
\end{array}$ & $\begin{array}{c}1 \\
(0,78 \%) \\
\end{array}$ & $\begin{array}{c}6 \\
(2,08 \%) \\
\end{array}$ \\
\hline Benar & $\begin{array}{c}61 \\
(38,12 \%)\end{array}$ & $\begin{array}{c}60 \\
(46,88 \%)\end{array}$ & $\begin{array}{c}121 \\
(42,01 \%)\end{array}$ \\
\hline
\end{tabular}

miskonsepsi saat pretets, miskonsepsi yang didapat pada saat posttest juga berdasarkan hasil pekerjaan dari siswa yang tergolong berkemampaun tinggi, sedang, dan rendah (lihat Gambar 5) menunjukkan hasil pekerjaan siswa berkemampuan sedang $\left(\mathrm{S}_{3}\right)$ pada Nomor tiga saat posttest dan sebagaian transkip hasil yang mengalami kesalahan dalam menentukan suku binomial. Dimana $\mathrm{S}_{3}$ menganggap suku binomial ditentukan dari keberadaan operasi penjumlahan dan pengurangan, kesalahan ini termasuk miskonsepsi generalisasi.

\section{3. iii. $x^{2}+2 x-3$}

Gambar 5. Hasil Pekerjaan $\mathrm{S}_{3}$ Posttest Nomor 3.

Peneliti : "Kenapa kamu menyebutkan ini (menunjukkan $\mathbf{x}^{2}+\mathbf{2 x}-\mathbf{3}$ ) adalah suku binomial?"

$S_{3} \quad:$ "Karena ada operasi penjumlahan dan penguranganya dua."

Peneliti : "Jadi yang merupakan suku binomial itu harus mempunyai operasi penjumlahan dan pengurangan, duaduannya harus ada?"

$\mathrm{S}_{3} \quad:$ (Menganggukan kepala)

Peneliti : "Lalu kenapa kamu menyebutkan yang nomor lima $y^{3}+2 y^{2}-y+2$ bukan suku binomial?
$S_{3} \quad$ : "Karena operasinya ada dua."

Peneliti : "Oh jadi kamu melihat suku dua itu dari banyaknya operasi?

$\mathrm{S}_{3} \quad: \quad$ (Menganggukan kepala)

Kesalahan konsep juga ditemukan pada hasil pekerjaan siswa berkemampuan tinggi yaitu $S_{9}$ pada nomor lima saat posttest. Dimana Sy mengalami kesalahan dalam mengoperasikan penjumlahan bentuk aljabar (lihat Gambar 6) dan sebagian transkip hasil wawancara menunjukkan bahwa $\mathrm{S}_{9}$ mengalami kesalahan dalam mengoperasikan penjumlahan bentuk aljabar $-20 x+25 x$ yaitu dengan demenganggap operasi penjumlahan sebagai perkalian atau konjoining operasi penjumlahan dan perkalian sehingga hasilnya $-5 x^{2}$. Karenanya, kesalahan ini termasuk miskonsepsi notasi. Selain itu, S9 pun tidak dapat menentukan metode yang digunakan selanjutnya, sehingga $S_{9}$ tidak dapat menyelesaikan secara tuntas.

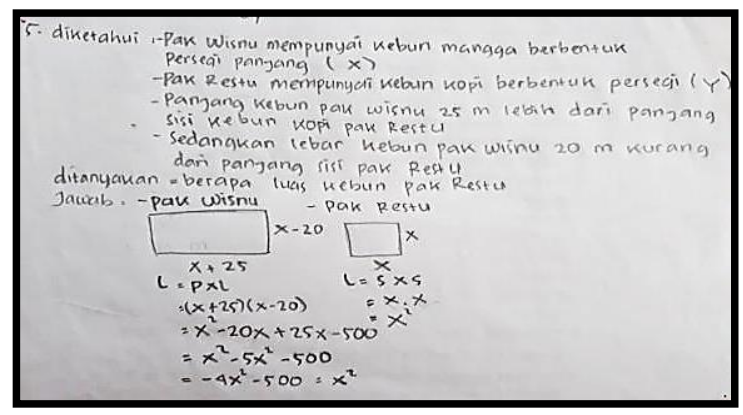

Gambar 6. Hasil Pekerjaan $\mathrm{S}_{9}$ Posttest Nomor 5.

Peneliti : "Oke, cara mengoperasikannya bagaimana? Jelaskan."

S9 : "X kuadrat dikurangi ... (Sambil menunjukkan jawaban siswa)"

Peneliti : "X kuadrat itu darimana?"

$S_{9} \quad: \quad$ "X kali $x, x$ kuadrat. (Sambil menunjukkan jawaban siswa)"

Peneliti : "Terus."

S9 : "X dikali dua puluh, dua puluh $x$. 


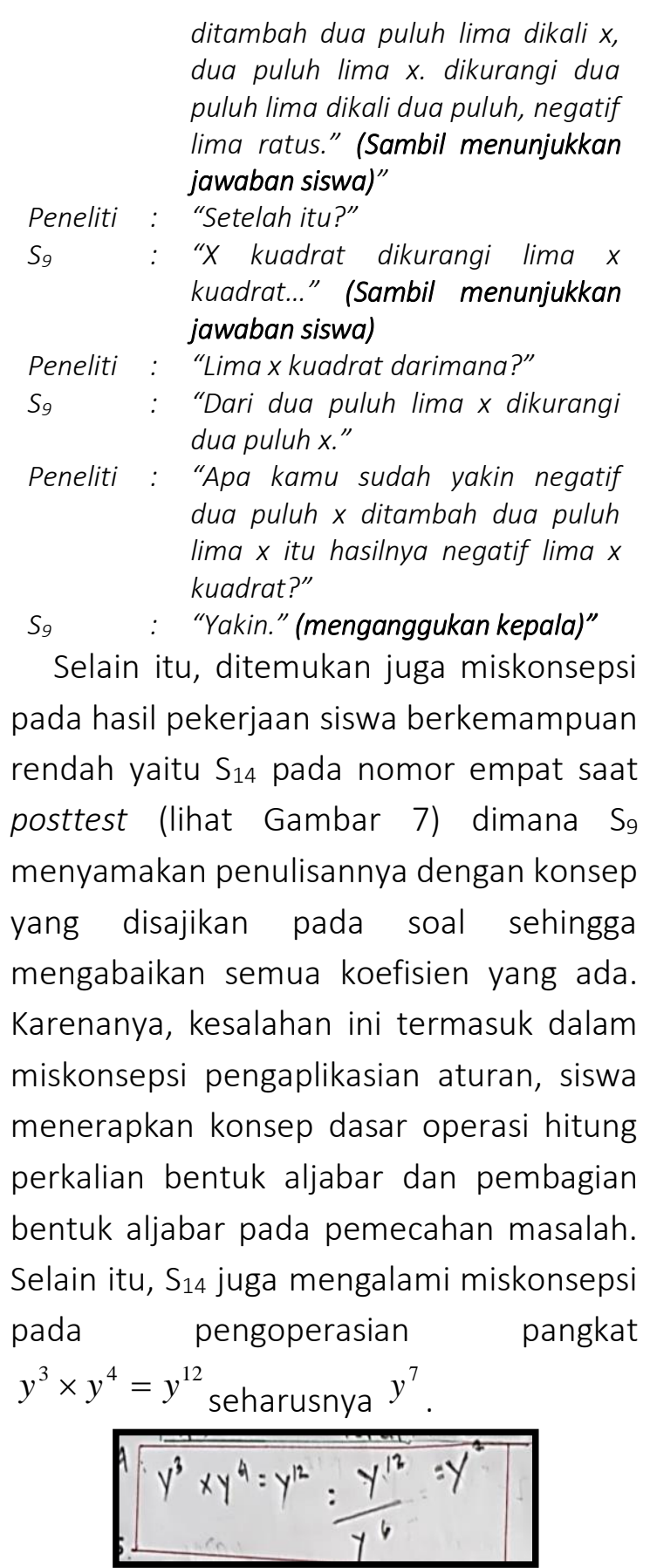

Gambar 7. Hasil Pekerjaan $\mathrm{S}_{14}$ Posttest Nomor 4.

Peneliti : "Baik, Cara kamu menyederhanakan bentuk ini dengan konsep ini seperti apa?Jelaskan"

$S_{14} \quad: \quad$ "3y dikali $4 y^{4}$."

Peneliti : "Iya. Tapi disini kamu menuliskan semuanya tanpa koefisien. Kenapa?"

$\mathrm{S}_{14} \quad$ : "Keliru."

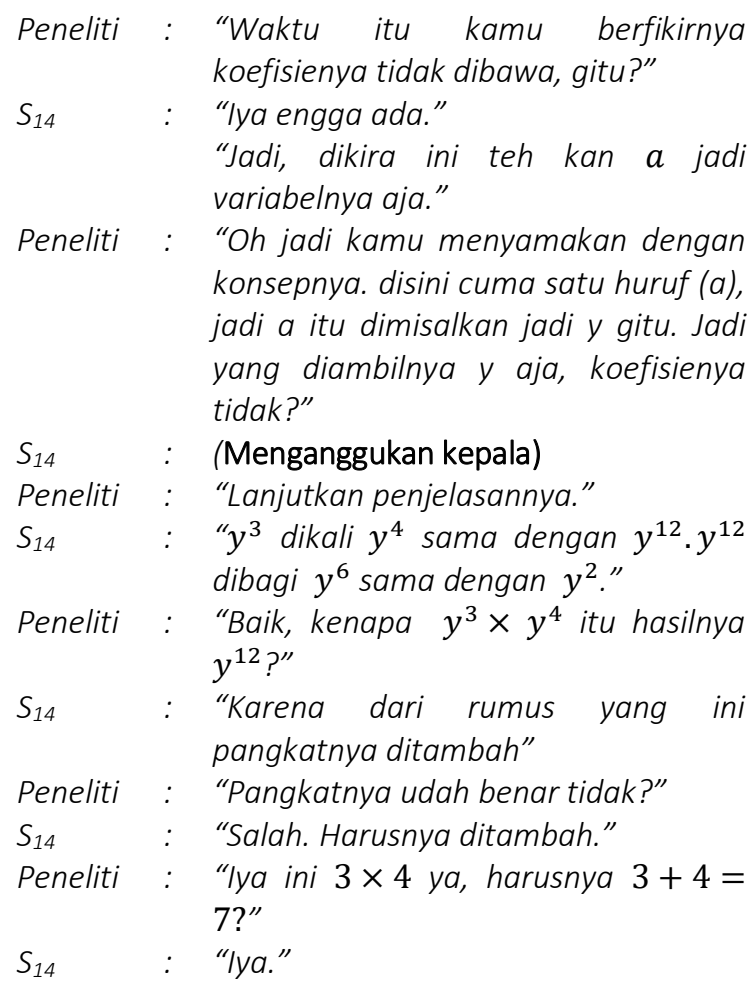

Peneliti : "Oh jadi kamu menyamakan dengan konsepnya. disini cuma satu huruf (a), jadi a itu dimisalkan jadi y gitu. Jadi yang diambilnya y aja, koefisienya tidak?"

$S_{14} \quad:$ (Menganggukan kepala)

Peneliti : "Lanjutkan penjelasannya."

$S_{14} \quad: \quad " y^{3}$ dikali $y^{4}$ sama dengan $y^{12} \cdot y^{12}$ dibagi $y^{6}$ sama dengan $y^{2}$."

Peneliti : "Baik, kenapa $y^{3} \times y^{4}$ itu hasilnya $y^{12}$ ?"

$S_{14}$ : "Karena dari rumus yang ini pangkatnya ditambah"

Peneliti : "Pangkatnya udah benar tidak?"

$\mathrm{S}_{14} \quad:$ "Salah. Harusnya ditambah."

Peneliti : "lya ini $3 \times 4$ ya, harusnya $3+4=$ 7?"

$\mathrm{S}_{14} \quad:$ "lya."

Berdasarkan hasil analisis miskonsepsi yang dialami siswa kelas VII-H di SMP Negeri 1 Cibatu, didapat bahwa dari berbagai macam hasil pekerjaan siswa ditemukan beberapa miskonsepsi dalam mengerjakan soal mengenai materi operasi hitung bentuk aljabar, baik saat pelaksanaan pretest maupun saat pelaksanaan posttest. Miskonsepsimiskonsepsi yang tampak pada hasil pekerjaan siswa selanjutnya dikategorikan berdasarkan materi yang terkait dengan miskonsepsi yang dialami oleh siswa.

\section{Kategori bentuk miskonsepsi} generalisasi, ditemukan pada semua soal baik bentuk uraian mupun option. Pada soal nomor satu bentuk uraian dan option yaitu mengenai unsur-unsur bentuk aljabar, siswa mengalami kesalahan dalam menentukan koefisien, variabel dan 
konstanta yaitu dengan menganggap koefisien sebagai konstanta begitupun sebaliknya. Selain itu, beberapa siswa pun menganggap koefisien terletak pada suku yang paling depan dan variabel terletak pada suku setelahnya, hal ini sejalan dengan penelitian Muntikoh (2017) dan Ramdhani, Hartoyo, \& Mirza (2015) yang menyebutkan siswa menganggap hanya angka di depan variabel yang merupakan koefisien. Pada soal nomor dua bentuk uraian dan option yaitu mengenai penyederhanaan bentuk aljabar, siswa mengalami kesalahan dalam mengoperasikan suku sejenis yaitu dengan menganggap suku yang memiliki variabel yang sama dengan pangkat berbeda merupakan suku sejenis, hal ini pun sejalan dengan penelitian Muntikoh (2017) dan Ramdani, Hartoyo, \& Mirza (2015) yang menyebutkan bahwa siswa yang mengalami miskonsepsi penjumlahan dua bentuk aljabar yang menganggap walaupun pangkat berbeda namun memiliki variabel yang sama maka dapat dijumlahkan. Selain itu, terdapat juga siswa yang kurang memahami operasi aritmatika, dimana siswa tidak dapat mengoperasikan penjumlahan dan pengurangan pada bentuk aljabar, hal ini sesuai dengan penelitian Wahyuni, Yusmin, \& Suratman (2016) yang menyebutkan ketidakmampuan menggeneralisasi karena kurang memahami operasi aritmatika. Pada soal nomor tiga bentuk uraian dan option yaitu mengenai klasifikasi bentuk aljabar berdasarkan jumlah suku, siswa mengalami kesalahan dalam menentukan suku binomial yaitu dengan menganggap bentuk aljabar berdasarkan jumlah suku dapat ditentukan dari jumlah variabel $x$, serta ada juga siswa yang menganggap bentuk aljabar berdasarkan jumlah suku dapat ditentukan dari jumlah notasi penjumlahan dan pengurangan, hal ini sesuai dengan penelitian yang dilakukan oleh Ramdani, Hartoyo, \& Mirza (2015) yang menyebutkan bahwa siswa menganggap suatu bentuk aljabar dikatakan binomial jika ada operasinya, ada juga siswa yang menganggap binomial sebagai bentuk yang memuat variabel $x$. Selain itu, dalam penelitian ini ditemukan juga siswa yang menganggap suku binomial berdasarkan jumlah suku dapat ditentukan dari jumlah keselurahan variabel, hal ini merupakan miskonsepsi baru yang ditemukan pada penelitian ini. Siswa menganggap bahwa suatu bentuk aljabar dikatakan suku apabila memuat variabel $x$ dan $y$, sehingga pada soal nomor tiga, seperti pada hasil pekerjaan $S_{14}$ yang mengalami kesalahan dalam menyertakan alasan mengenai suku binomial, dimana $\mathrm{S}_{14}$ menganggap suku binomial dapat ditentukan dari keberadaan variabel $x$ dan $y$. Oleh karena itu, kesalahan ini termasuk dalam miskonsepsi Generalisasi.

Pada soal nomor empat bentuk uraian yaitu mengenai operasi perkalian dan pembagian, siswa mengalami kesalahan dalam mengoperasikan koefisien, hal ini 
sejalan dengan penelitian Wahyuni, Yusmin, \& Suratman (2016) yang menyebutkan ketidakmampuan menggeneralisasi karena kurang memahami operasi aritmatika. Sedangkan pada bentuk soal option yaitu mengenai representasi matematika, siswa mengalami kesalahan dalam menentukan metode, dimana siswa tidak dapat menentukan metode sebagai bentuk alasan yang menunjukkan pernyataan dari soal tersebut merupakan benar. Hal ini sejalan dengan penelitian Muntikoh (2017) yang menyebutkan bahwa siswa tidak mampu menggeneralisasikan karena tidak mampu untuk menentukan metode yang digunakan. Pada soal nomor lima bentuk uraian yaitu mengenai soal cerita, siswa mengalami kesalahan dalam operasi aritmatika, dimana siswa tidak dapat mengoperasikan sifat distributif perkalian, hal ini sejalan dengan penelitian Wahyuni, Yusmin, \& Suratman (2016) yang menyebutkan ketidakmampuan menggeneralisasi karena kurang memahami operasi aritmatika.

Kategori bentuk miskonsepsi notasi, ditemukan pada soal nomor satu bentuk uraian, soal nomor dua baik bentuk uraian maupun option, soal nomor empat bentuk uraian, dan soal nomor lima bentuk urain. Pada soal nomor satu bentuk uraian yaitu mengenai unsur-unsur bentuk aljabar, siswa mengalami kesalahan dalam menentukan koefisien, yaitu dengan menganggap notasi negatif $(-)$ bukan merupakan satu kesatuan. Pada soal nomor dua bentuk uraian dan option yaitu mengenai penyederhanaan bentuk aljabar, siswa mengalami kesalahan dalam mengoperasikan suku sejenis, yaitu dengan menganggap notasi negatif $(-)$ bukan merupakan satu kesatuan (Ramdani, Hartoyo, \& Mirza, 2015; Muntikoh, 2017) yang menyebutkan siswa menganggap simbol operasi bukan bagian dari jawaban. Selain itu, ditemukan juga siswa yang mengalami konjoining operasi penjumlahan dan perkalian, hal ini sesuai dengan penelitian Ramdani, Hartoyo, \& Mirza (2015) yang menyebutkan bahwa siswa mengalami miskonsepsi pada konsep penjumlahan dua bentuk aljabar dengan memahami notasi penjumlahan sebagai perkalian. Pada soal nomor empat bentuk uraian yaitu mengenai operasi hitung perkalian dan pembagian, siswa mengalami kesalahan dalam mengoperasikan pangkat, yaitu dengan mengabaikan keberadaan notasi pangkat, hal ini sesuai dengan penelitian yang dilakukan oleh Muntikoh (2017) dimana siswa mengalami kesalahan dalam aturan pangkat. Sedangkan pada soal nomor lima uraian yaitu mengenai soal cerita, siswa mengalami kesalahan dalam mengoperasikan bentuk aljabar, dimana siswa menganggap notasi negatif (-) bukan merupakan satu kesatuan, hal ini sama dengan pada soal nomor satu dan dua bentuk uraian maupun option. 
Kategori bentuk miskonsepsi pengartian huruf, ditemukan pada soal nomor empat baik bentuk uraian maupun option dan soal nomor lima bentuk uraian. Pada soal nomor empat bentuk uraian yaitu mengenai operasi perkalian dan pembagian, siswa mengalami kesalahan yaitu dengan mengabaikan keberadaan variabel. Sedangkan pada bentuk option yaitu mengenai representasi matematika, dimana siswa menganggap variabel sebagai label. Pada soal nomor lima bentuk uraian mengenai soal cerita, siswa menganggap variabel dapat dimisalkan dengan suatu bilangan. Selain itu, ditemukan juga siswa yang mengalami kesalahan dalam mengartikan soal ke bentuk matematika, hal ini merupakan miskonsepsi baru yang ditemukan pada penelitian ini. Dalam soal cerita, siswa tidak mampu mengartikan atau mengubah soal cerita dalam bentuk matematika yang tidak lain akan menggunakan variabel. Seperti yang ditemukan pada hasil pekerjaan ketiga partisipan, untuk menemukan luas kebun Pak Restu, ketiga partisipan tidak mengubah terlebih dahulu soal dalam bentuk matematika. Melainkan langsung memasukkan besaran-besaran yang terdapat pada soal cerita ke dalam rumus untuk mencari luas kebun Pak Restu.

Kategori bentuk miskonsepsi pengaplikasian aturan, ditemukan pada soal nomor dua baik bentuk uraian maupun option, soal nomor empat bentuk uraian dan lima bentuk uraian. Pada soal nomor dua bentuk uraian dan option yaitu mengenai penyederhanaan bentuk aljabar, siswa mengalami kesalahan dalam manipulasi bentuk aljabar. Pada soal nomor empat bentuk uraian yaitu mengenai konsep operasi hitung perkalian dan pembagian, dimana siswa menerapkan konsep kanselasi, hal ini sejalan dengan penelitian Herutomo (2017). Selain menerapkan konsep kanselasi, beberapa siswa juga menerapkan operasi perkalian pada notasi pangkat perkalian bentuk aljabar, serta operasi pembagian pada notasi pangkat pembagian bentuk aljabar, hal tersebut merupakan bentuk miskonsepsi baru yang ditemukan pada penelitian ini, beberapa siswa menerapkan operasi yang sesuai dengan notasi pada soal, seperti pada hasil pekerjaan $\mathrm{S}_{14}$ pretest, dimana dalam mengoprasikan perkalian $\left(3 y^{3} \times 4 y^{4}\right) \mathrm{S}_{14}$ mengaplikasikan operasi perkalian pada pangkatnya juga, sehingga hasilnya menjadi $12 y^{12}$. Selain itu, ditemukan juga siswa yang menerapkan konsep dasar operasi hitung perkalian bentuk aljabar dan operasi hitung pembagian bentuk aljabar pada pemecahan masalah yaitu pada hasil pekerjaan $\mathrm{S}_{14}$ posttest, dimana siswa menganggap penulisan pada pemecahan masalah harus sesuai dengan penulisan konsep dasarnya. Sehingga dalam menyelesaikan soal operasi hitung bentuk aljabar $\left(3 y^{3} \times 4 y^{4}\right) \div 6 y^{5}, \quad \mathrm{~S}_{14}$ menghilangkan koefisien dan menyamakan penulisannya dengan konsep 
dasar $a^{n}=a^{m+n} ; \frac{a^{m}}{a^{n}}=a^{m-n}$, sehingga hasil akhirnya menjadi $y^{3} \times y^{4}=y^{7} \div$ $y^{6}=y^{2}$.

Pada soal nomor lima bentuk uraian yaitu mengenai soal cerita, siswa mengalami kesalahan dalam menerapkan sifat distributif perkalian, dimana siswa menerapkan pengelompokkan suku sejenis pada sifat distributif, serta menerapkan prinsip yang berada didalam kurung harus dioperasikan terlebih dahulu (Ramdani, Hartoyo, \& Mirza, 2015; Efendi, 2017; Muntikoh, 2017).

\section{Penutup}

Bentuk miskonsepsi yang dialami siswa dibedakan menjadi empat kategori yang dapat dijabarkan sebagai berikut: miskonsepsi generalisasi, miskonsepsi notasi, miskonsepdi pengartian huruf, dan miskonsepsi aplikasi aturan. Guru perlu bersikap waspada terhadap keempat miskonsepsi ini, sehingga tidak mengalami kesulitan yang berarti dalam proses belajar mengajar pada materi aljabar.

\section{Daftar Pustaka}

Afriansyah, E. A. (2012). Design Research: Konsep Nilai Tempat pada Penjumlahan Bilangan Desimal (Doctoral dissertation, Tesis yang tidak dipublikasikan berasal dari Beasiswa DIKTI dengan program IMPoME (International Master Program on Mathematics Education). Universitas Sriwijaya PalembangUniversitas UTRECHT Belanda).
Afriansyah, E. A. (2013). Design Research: Mengukur Kepadatan Bilangan Desimal. In Seminar Nasional Matematika dan Pendidikan Matematika STKIP Siliwangi (Vol. 1).

Afriansyah, E. A. (2014). Addition and Substraction Numbers up to 10 through PMRI for SD/MI Level Students. International Postgraduate Colloqium of Research in Education 3rd IPCORE.

Afriansyah, E. A. (2015). Students' Misconception in Decimal Numbers. In International Seminar on Teacher Education 1st ISTE UIN Suska Riau.

Afriansyah, E. A. (2016). Enhancing Mathematical Problem Posing via Realistic Approach. International Seminar on Mathematics. Science, and Computer Science Education MSCEIS.

Afriansyah, E. A., Puspitasari, N., Luritawaty, I. P., Mardiani, D., \& Sundayana, R. (2019, December). The analysis of mathematics with ATLAS. ti. In Journal of Physics: Conference Series (Vol. 1402, No. 7, p. 077097). IOP Publishing.

Clement, J. (1982). Algebra word problem solutions: Thought processes underlying a common misconception. Journal for research in mathematics education, 16-30.

Efendi, M. A. (2017). Miskonsepsi Siswa Sekolah Menengah Pertama (SMP) pada Pokok Bahasan Bentuk Aljabar. (Skripsi). Universitas Pendidikan Indonesia, Bandung. 
Herutomo, R. A. (2017). Miskonsepsi Aljabar: Konteks Pembelajaran Matematika pada Siswa Kelas VIII SMP. Jurnal Pendidikan Dasar, 1(1), 18.

Herutomo, R. A., \& Saputro, T. E. M. (2014). Analisis Kesalahan dan Miskonsepsi Siswa Kelas VIII pada Materi Aljabar. Edusentris, Jurnal IImu Pendidikan dan Pengajaran, 1(2), 134145.

Iryani, I., Tandililing, E., \& Hamdani, H. (2018). Remediasi Miskonsepsi Siswa dengan Model Pembelajaran Children Learning in Science (CLiS) Berbantuan Simulasi PhET. Jurnal Pendidikan dan Pembelajaran Khatulistiwa, 7(4).

Jumadi, S., \& Hamdani, H. (2018). Menggali Miskonsepsi Siswa SD tentang Tata Surya Secara Lisan dalam Bahasa Dayak Suaid. Jurnal Pendidikan dan Pembelajaran Khatulistiwa, 7(5).

Muntikoh, N. (2017). Strategi pembelajaran pencapaian konsep dalam pembelajaran matematika untuk meminimalisasi miskonsepsi matematika siswa (Bachelor's thesis).

Nurmawanti, I., \& Sulandra, I. M. (2020). Exploring of Student's Algebraic Thinking Process through Pattern Generalization using Similarity or Proximity Perception. Mosharafa: Jurnal Pendidikan Matematika, 9(2), 191-202.

Pendidikan, B. S. N. (2006). Standar isi. Jakarta: BSNP.
Ramadhani, W. H., Hartoyo, A., \& Mirza, A. (2015). Miskonsepsi Siswa Pada Materi Operasi Pada Bentuk Aljabar Kelas VII SMP Haebat Islam (Doctoral dissertation, Tanjungpura University).

Sugiyono. (2018). Metode Penelitian Pendidikan Matematika. Bandung: Alfabeta.

Utami, R. (2017). Analisis Miskonsepsi Siswa dan Cara Mengatasinya pada Materi Bentuk Aljabar Kelas VII-C SMP Negeri 13 Malang. Jurnal Pendidikan Matematika, 3(1), 37-44.

Wahyuni, T. N., Yusmin, E., \& Suratman, D. (2016). Miskonsepsi Siswa pada Penjumlahan dan Pengurangan Bentuk Akar di Kelas X SMKN 1 Pontianak (Doctoral dissertation, Tanjungpura University).

\section{Riwayat Hidup Penulis}

Herikeu Meidia Sari, S.Pd.

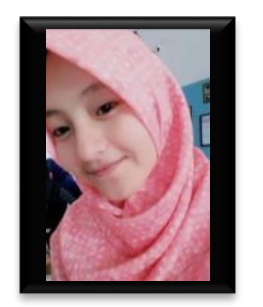

Lahir di Garut, 15 Oktober 1996. Staf pengajar di institusi mana. Studi S1 Pendidikan Matematika Institut Pendidikan Indonesia, Garut, lulus tahun 2020.

\section{Ekasatya Aldila Afriansyah, M.Sc.}

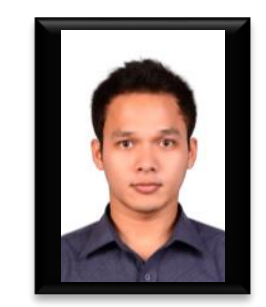

Lahir di Bandung, 4 April 1986. Dosen Tetap Yayasan STKIP Garut. Studi S1 Matematika Konsentrasi Statistika UPI, Bandung, lulus tahun 2009; S2 Pendidikan Matematika UNSRIUtrecht, lulus tahun 2012. 